\title{
THE TRANSMUTATION MODELING FOR PLUTONIUM AND MINOR ACTINIDES IN THE TWO-ZONE SUBCRITICAL REACTOR
}

\author{
V.I. Gulik ${ }^{1,2}$, D.O. Sheliahovskyi ${ }^{2}$, A.V. Nosovskyi ${ }^{1}$ \\ ${ }^{1}$ Institute for Safety Problems of NPP, Kyiv, Ukraine; \\ ${ }^{2}$ PJSC "SRPA “Impulse”, Lugansk region, Severodonetsk, Ukraine \\ E-mail: volodymyr.gulik@gmail.com
}

The investigations directed to plutonium and minor actinides transmutations for two-zone subcritical reactor is considered in present paper. The distributions of thermal and fast neutrons in the subcritical system were obtained. The distributions of fission and capture reaction rates for ${ }^{237} \mathrm{~Np}$ and ${ }^{243} \mathrm{Am}$ were analyzed from viewpoint of minor actinides transmutation. The transmutation simulations for different distributions of pin targets were carried out within the scope of this paper. The obtained modeling results for different nuclear waste isotopes were analyzed and discussed.

\section{INTRODUCTION}

Despite the fact that nuclear energy now faces many challenges, many countries (such as China, India, etc.) continue to consider nuclear energy as a reliable, clean and economical source of energy. The rapid development of nuclear energy in these countries will result in the accumulation of high-level radioactive waste. This waste is usually divided into minor actinides (MA) and long-lived fission products (LLFP) [1]. The technology of transmutation of radioactive waste allows the transfer of long-lived radioactive isotopes into shortlived or stable isotopes [2]. Transmutation of MA is best implemented in reactor systems with a fast neutron spectrum, and the transmutation of LLFP is best implemented in reactor systems with a thermal neutron spectrum [3].

The accelerator driven systems (ADS) are advanced nuclear systems, which are particularly suitable for transmutation objectives. Such nuclear systems may be employed to address several missions, for example nuclear waste transmutation and electricity generation. ADS presents several benefits: more flexible with respect to fuel composition and potentially raised safety. As the issue of spent fuel management is one of the most important of the future nuclear energy development in the world, the study of transmutation possibilities also relevant. There are many international projects in this way, for example: MYRRHA [4], YALINA [5], SAD etc., and Ukraine is no exception. We have already built a subcritical system with an electron accelerator in Kharkiv [6], and in the nearly future, it is planned to be launched.

In this work, the authors' main focus is on transmutation investigation of two-zone subcritical reactor driven by high-intensity neutron generator.

\section{MODELING SCHEME AND CALCULATION METHODS}

Based on the considerations and studies presented in our previous papers [7-12], this research model is a two-zone one. The presented subcritical system has two zones with different neutron spectrum. A graphite moderator was added to arrange the thermal neutron spectrum in the outer zone. The scheme with light water moderator and coolant is used, was not considered due to the risk of light water getting into the inner zone during an emergency and a significant splash of reactivity, as a result. Helium was selected to be a coolant in the internal and external zones.

During the model development, it was decided to use a powerful neutron generator as an external source of neutrons. Such installation generates a $14 \mathrm{MeV}$ neutrons flow as a result of $(\mathrm{D}, \mathrm{T})$ reaction.

Thus, the presented subcritical system has two zones with different neutron spectrum, which is relevant for conducting MA and LLFP transmutations simultaneously. To obtain the thermal spectrum in the outer zone, a moderator is used. Graphite was chosen as a moderator. The use of water as a moderator is not reasonable in terms of safety since the inner zone has a fast neutron spectrum and the water entry into the inner zone can lead to the increase of the subcritical system effective neutron multiplication factor. Helium is used as a coolant both in the inner and in the outer zones. The general view of the subcritical system is shown in Fig. 1.

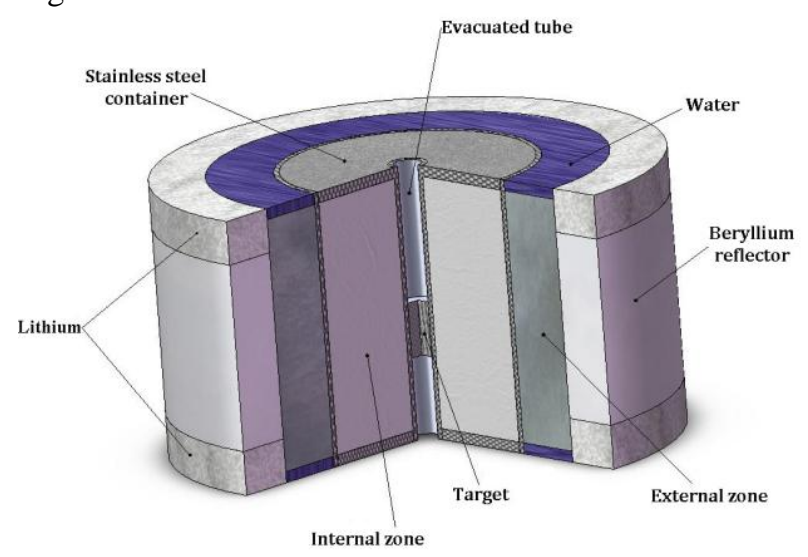

Fig. 1. The general view of a two-zone research subcritical reactor

Shortened fuel pins for WWER-1000 reactors were selected for the fuel elements geometry modeling. Fuel pin cladding is an alloy of zirconium with $1 \%$ niobium, the fuel pin diameter is $0.91 \mathrm{~cm}$, and the diameter of the fuel element is $0.786 \mathrm{~cm}$. The fuel element is uranium dioxide. Enrichment of ${ }^{235} \mathrm{U}$ for the inner zone is $10 \%$, and for the fuel pins of the outer zone it is equal to $5 \%$. Fuel density is $10.96 \mathrm{~g} / \mathrm{cm}^{3}$. The fuel pin pitch is $1.275 \mathrm{~cm}$ in the inner zone, and $5 \mathrm{~cm}$ in the outer zone; the fuel pins layout in the core is square. In the outer 
zone fuel pins cooling is carried out through a circular channel with a diameter of $1.275 \mathrm{~cm}$. Low level of the enrichment was chosen according to the IAEA recommendations on reducing the level of the ${ }^{235} \mathrm{U}$ enrichment in subcritical reactor projects [13].

Charged particles (deuterons) move from the accelerator along the central tube with a thickness of $1 \mathrm{~cm}$ and fall on the titanium target saturated with tritium (see Fig. 1). The D-T reaction results in the fast neutrons external flow with energy of $14 \mathrm{MeV}$. The titanium target is located on a copper lining. Cooling is carried out with water. There is an inner (fast) zone of $40.5 \mathrm{~cm}$ radius is around the central tube; it is placed in a stainless steel tank with a thickness of $1 \mathrm{~cm}$. The outer zone surrounds the inner zone and its radius is $89.9 \mathrm{~cm}$. There is a beryllium reflector with a thickness of $5 \mathrm{~cm}$ around it. The height of the model is taken equal to the system diameter, which is $179.8 \mathrm{~cm}$ and, together with the beryllium reflector, minimizes the neutrons leakage.

The modeling of the present system was carried out using the Monte Carlo Serpent code [14]. The main characteristics of the system are presented in Table 1; the results of the geometry construction are shown in Figs. 2, 3.

Table 1

The main characteristics of the subcritical system

\begin{tabular}{|l|c|}
\hline \multicolumn{1}{|c|}{ Parameter } & Value \\
\hline Burning capacity, $\mathrm{kW}$ & 957.7 \\
\hline Neutron energy of external source, $\mathrm{MeV}$ & 14 \\
\hline $\begin{array}{l}\text { Number of neutrons generated by the } \\
\text { target, neutrons/s }\end{array}$ & $3.2 \mathrm{E}+14$ \\
\hline Core height, cm & 179.8 \\
\hline Inner zone diameter, cm & 40.5 \\
\hline Outer zone diameter, cm & 89.9 \\
\hline Beryllium reflector thickness, cm & 5 \\
\hline Inner zone $\mathrm{UO}_{2}$ enrichment, \% & 10 \\
\hline Outer zone $\mathrm{UO}_{2}$ enrichment, \% & 5 \\
\hline Number of inner zone fuel pins & 3011 \\
\hline Number of outer zone fuel pins & 751 \\
\hline
\end{tabular}

\section{SERPENT MODELING RESULTS}

\subsection{ANALYSIS OF THE BASIC NEUTRON CHARACTERISTICS IMPORTANT FOR THE RADIOACTIVE WASTE TRANSMUTATION}

Before MA transmutation calculating in the present subcritical system, it was decided to investigate the neutron fluxes distribution in fast and thermal zones (Fig. 4) and the distribution of the fission and capture reactions rates for the main MA isotopes, namely ${ }^{237} \mathrm{~Np}$ and ${ }^{243} \mathrm{Am}$ (Figs. 5, 6, respectively). Since these reaction channels are competing, and we are interested in the division itself, a special coefficient ("alpha" = RR (fission)/RR (capture)) which shows the ratio of the fission reactions rates to the capture ones, or the number of fissions per capture, is introduced (Fig. 7).

The presented distribution of the transmutation coefficient "alpha" shows that, in terms of the transmutation rate, the central location of fuel with MA inclusion is the most effective one.

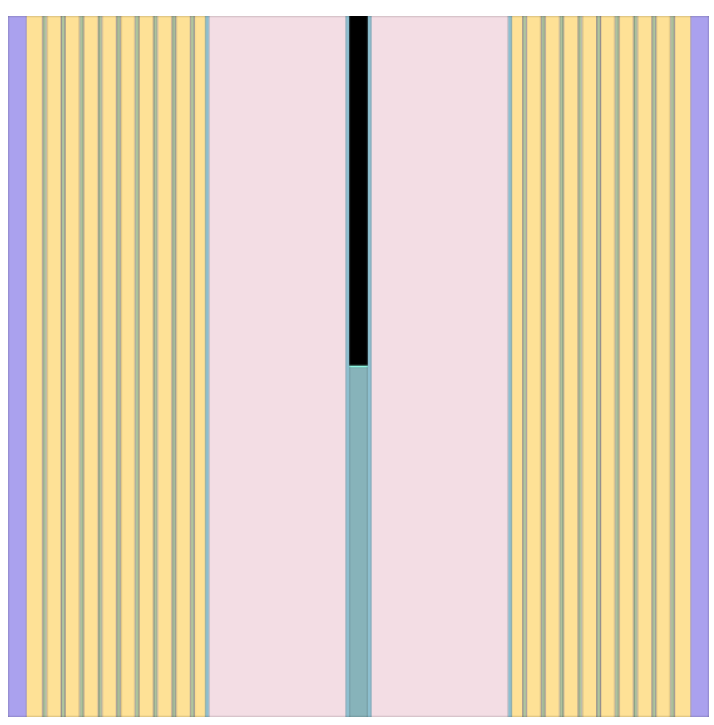

Fig. 2. The vertical cross-section of a cylindrical subcritical system modeled using the Serpent code

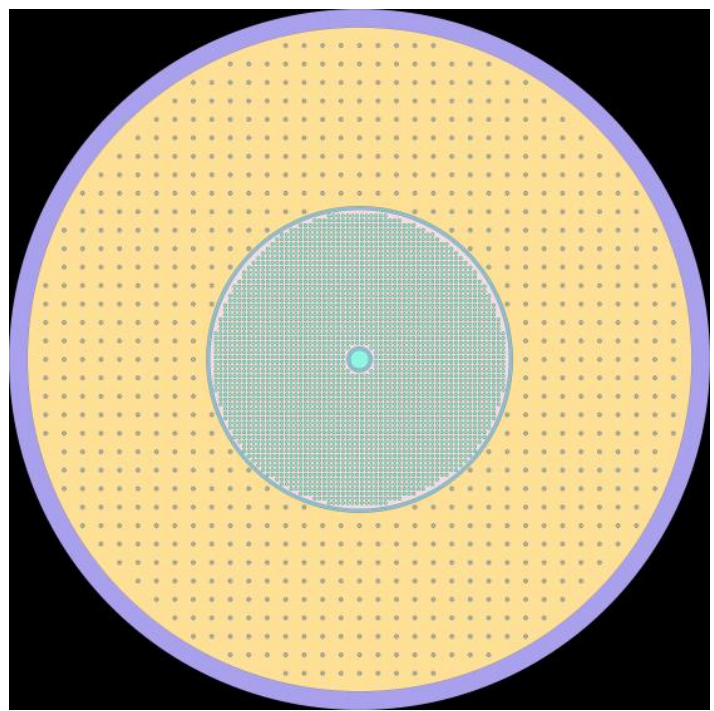

Fig. 3. Cross section of a cylindrical two-zone subcritical system modeled using Serpent code

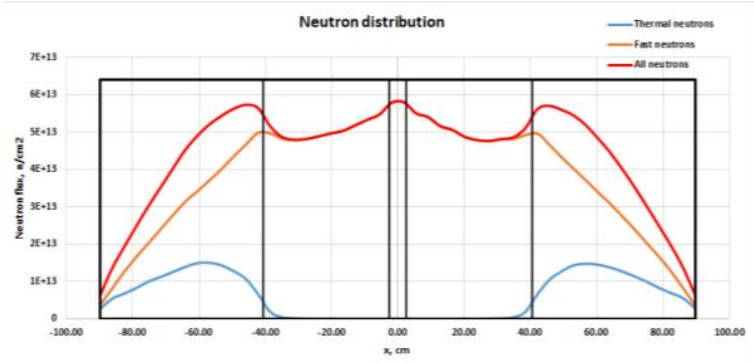

Fig. 4. Distribution of thermal and fast neutrons in the subcritical system

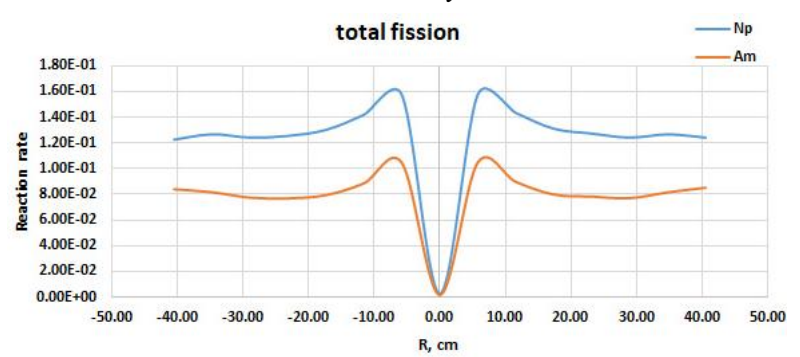

Fig. 5. Distribution of the fission reactions rates for

${ }^{237} \mathrm{~Np},{ }^{243} \mathrm{Am}$ in the inner zone of the subcritical system 


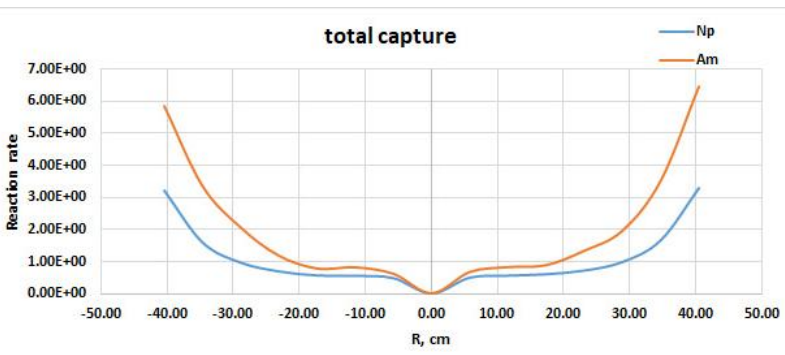

Fig. 6. Distribution of the capture reactions rates for

${ }^{237} \mathrm{~Np},{ }^{243} \mathrm{Am}$ in the inner zone of the subcritical system

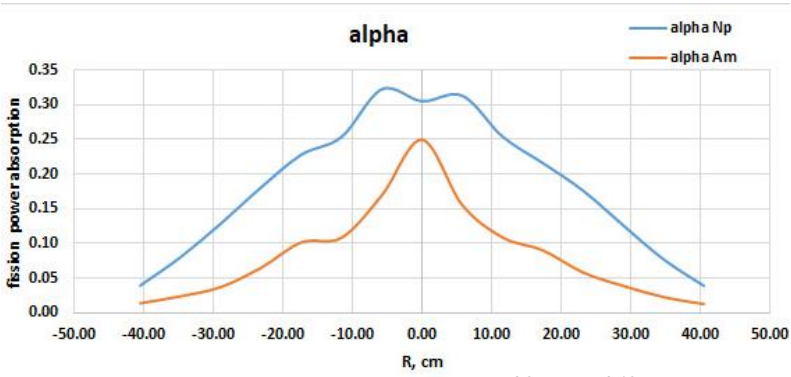

Fig. 7. Distribution of "alpha" for ${ }^{237} \mathrm{~Np},{ }^{243} \mathrm{Am}$ in the inner zone of the subcritical system

\subsection{CALCULATION OF MINOR ACTINIDES TRANSMUTATION IN THE FAST $Z$ OF SUBCRITICAL SYSTEM}

Two variants of the MA location in the subcritical system core were chosen based on the results of the neutron characteristics calculation and the calculations presented in [15]: heterogeneous (central) and homogeneous (in the form of concentric circles) (Figs 8,9 , respectively). The material composition of the fuel elements containing the MA was chosen on the basis of [15] and [16]. It is presented in Table 2.

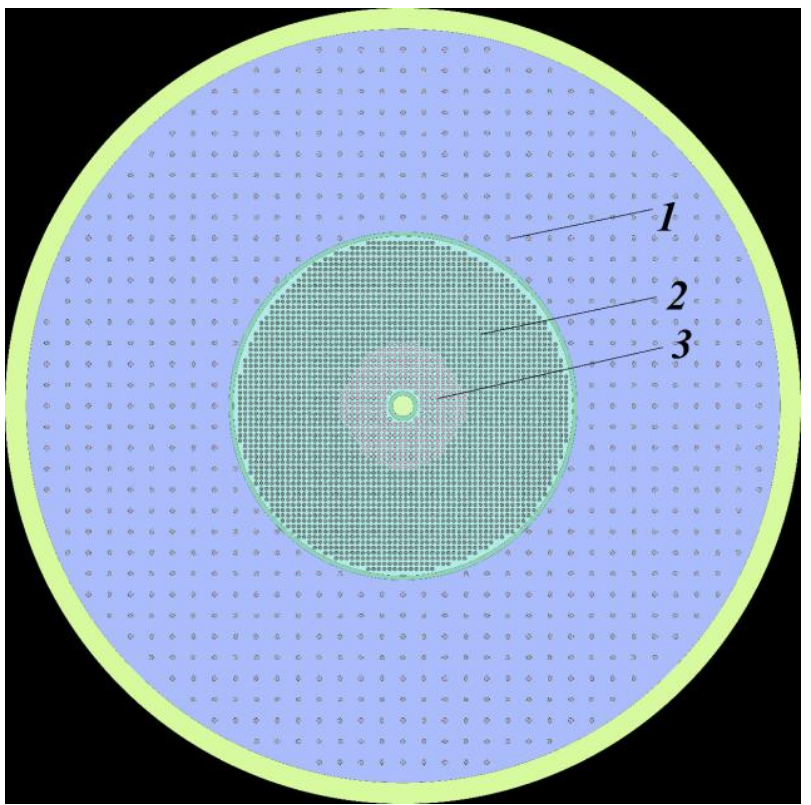

Fig. 8. Heterogeneous (central) layout of fuel elements $(P u+M A)$ in the core: 1 -thermal zone fuel element with $5 \%$ enriched fuel $\mathrm{UO}_{2} ; 2$ - fast zone fuel element with $10 \%$ enriched fuel $\mathrm{UO}_{2} ; 3$-fuel element with fuel $P u+M A$

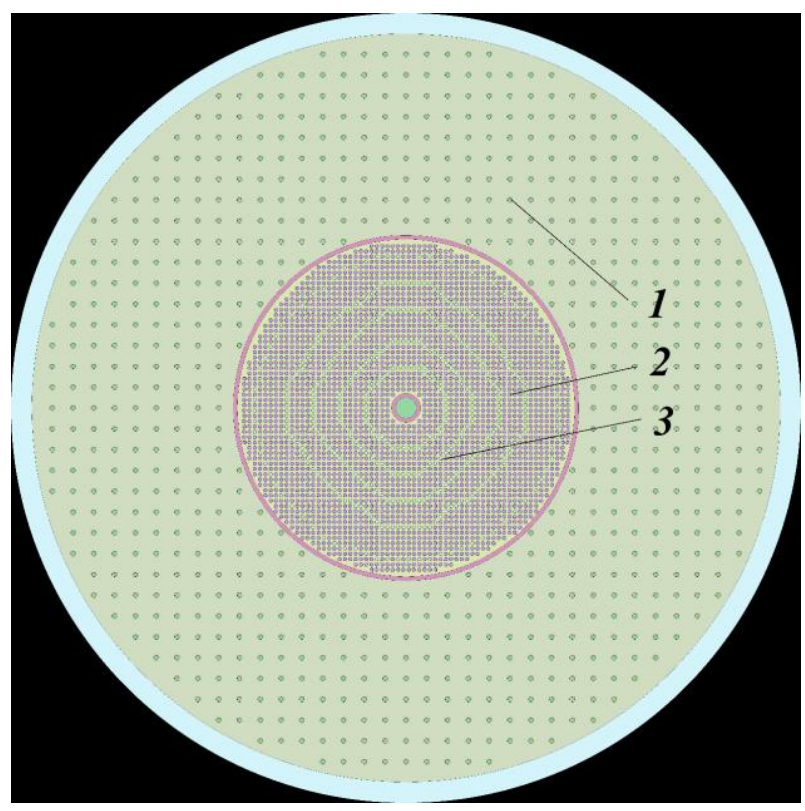

Fig. 9. Homogeneous layout of fuel elements (Pu+MA) in the core: 1 -thermal zone fuel element with $5 \%$ enriched fuel $\mathrm{UO}_{2} ; 2$-fast zone fuel element with $10 \%$ enriched fuel $\mathrm{UO}_{2} ; 3$ - fuel element with fuel $\mathrm{Pu}+\mathrm{MA}$

Table 2

Material composition of the fuel element Pu+MA [16]

\begin{tabular}{|c|c|}
\hline Isotope & Weight percent, \% \\
\hline $\mathrm{Pu} / \mathrm{Am} / \mathrm{Cm} / \mathrm{Mg} / \mathrm{O}$ & $23.48 / 30.63 / 6.12 / 19.37 / 20.39$ \\
\hline $\begin{array}{c}\mathrm{Pu}-238 / \mathrm{Pu}-239 / \mathrm{Pu}- \\
240 / \mathrm{Pu}-241 / \mathrm{Pu}-242\end{array}$ & $5.06 / 37.91 / 30.31 / 13.21 / 13.51$ \\
\hline $\mathrm{Am}-241 / \mathrm{Am}-243$ & $66.67 / 33.33$ \\
\hline $\mathrm{Cm}-244 / \mathrm{Cm}-245$ & $90 / 10$ \\
\hline
\end{tabular}

The number of elements with fuel Pu+MA is equal to both layouts in the inner zone of the subcritical system. It is 396 pins, which is up to approximately $13 \%$ of the fuel pins total number in the inner (fast) zone.

The burnup calculation was carried out with a 30-day step during 360 days at the nominal power level of the subcritical system. The calculation results of the isotopic composition in elements with fuel $\mathrm{Pu}+\mathrm{MA}$ are presented in Tables 3, 4 .

Table 3

Main isotopes concentrations comparison in case of the elements with fuel $\mathrm{Pu}+\mathrm{MA}$ burnup

\begin{tabular}{|c|c|c|c|}
\hline \multirow{2}{*}{ Isotope } & \multicolumn{3}{|c|}{ Atomic density, 1/barn·cm } \\
\cline { 2 - 4 } & $\begin{array}{c}\text { Initial } \\
\text { (with 0 } \\
\text { burnup) }\end{array}$ & $\begin{array}{c}\text { Heterogeneous } \\
\text { layout } \\
360 \text { days }\end{array}$ & $\begin{array}{c}\text { Homogeneous } \\
\text { layout } \\
360 \text { days }\end{array}$ \\
\hline${ }^{238} \mathrm{Pu}$ & $1.83 \mathrm{E}-04$ & $2.34 \mathrm{E}-04$ & $2.61 \mathrm{E}-04$ \\
\hline${ }^{239} \mathrm{Pu}$ & $1.36 \mathrm{E}-03$ & $1.23 \mathrm{E}-03$ & $1.21 \mathrm{E}-03$ \\
\hline${ }^{240} \mathrm{Pu}$ & $1.08 \mathrm{E}-03$ & $1.09 \mathrm{E}-03$ & $1.09 \mathrm{E}-03$ \\
\hline${ }^{241} \mathrm{Pu}$ & $4.71 \mathrm{E}-04$ & $4.14 \mathrm{E}-04$ & $4.25 \mathrm{E}-04$ \\
\hline${ }^{242} \mathrm{Pu}$ & $4.80 \mathrm{E}-04$ & $4.99 \mathrm{E}-04$ & $5.11 \mathrm{E}-04$ \\
\hline${ }^{241} \mathrm{Am}$ & $3.10 \mathrm{E}-03$ & $2.83 \mathrm{E}-03$ & $2.79 \mathrm{E}-03$ \\
\hline${ }^{243} \mathrm{Am}$ & $1.54 \mathrm{E}-03$ & $1.43 \mathrm{E}-03$ & $1.41 \mathrm{E}-03$ \\
\hline${ }^{244} \mathrm{Cm}$ & $8.26 \mathrm{E}-04$ & $8.27 \mathrm{E}-04$ & $8.66 \mathrm{E}-04$ \\
\hline${ }^{245} \mathrm{Cm}$ & $9.14 \mathrm{E}-05$ & $9.97 \mathrm{E}-05$ & $1.04 \mathrm{E}-04$ \\
\hline
\end{tabular}


Table 4

Volume of min isotopes production in fast and thermal zones during burnup (360 effective days)

\begin{tabular}{|c|c|c|}
\hline \multirow{2}{*}{ Isotope } & \multicolumn{2}{|c|}{ Atomic density, $1 /($ barn $\cdot \mathrm{cm})$} \\
\cline { 2 - 3 } & Fast zone & Thermal zone \\
\hline${ }^{238} \mathrm{Pu}$ & $7.30 \mathrm{E}-07$ & $3.94 \mathrm{E}-06$ \\
\hline${ }^{239} \mathrm{Pu}$ & $2.26 \mathrm{E}-04$ & $9.51 \mathrm{E}-05$ \\
\hline${ }^{240} \mathrm{Pu}$ & $7.06 \mathrm{E}-06$ & $6.05 \mathrm{E}-05$ \\
\hline${ }^{241} \mathrm{Pu}$ & $7.70 \mathrm{E}-07$ & $3.43 \mathrm{E}-05$ \\
\hline${ }^{242} \mathrm{Pu}$ & $1.02 \mathrm{E}-08$ & $1.93 \mathrm{E}-05$ \\
\hline${ }^{241} \mathrm{Am}$ & $9.29 \mathrm{E}-09$ & $3.41 \mathrm{E}-07$ \\
\hline${ }^{243} \mathrm{Am}$ & $2.84 \mathrm{E}-10$ & $3.87 \mathrm{E}-06$ \\
\hline${ }^{244} \mathrm{Cm}$ & $9.59 \mathrm{E}-12$ & $1.21 \mathrm{E}-06$ \\
\hline${ }^{245} \mathrm{Cm}$ & $1.03 \mathrm{E}-13$ & $6.58 \mathrm{E}-08$ \\
\hline
\end{tabular}

After assessing the burnup process of ${ }^{239} \mathrm{Pu},{ }^{241} \mathrm{Pu}$, ${ }^{241} \mathrm{Am},{ }^{243} \mathrm{Am}$, and ${ }^{244} \mathrm{Cm},{ }^{245} \mathrm{Cm}$, it can be concluded that a homogeneous layout of elements with fuel $\mathrm{Pu}+\mathrm{MA}$ is more effective in terms of the isotopes $\mathrm{Pu}$ and $\mathrm{Am}$ transmutation efficiency. It can be seen, that the isotopes $\mathrm{Cm}$ concentration increases during the process of burnup, the obtained results are correlated with the results presented in the article [15]. According to the results of the same article, the isotopes $\mathrm{Np}$ behavior (with respect to the transmutation time) is approximately the same with the isotopes Am.

Also, the subcritical system operation is accompanied by a process of the plutonium and americium isotopes production in the fuel elements $\mathrm{UO}^{2}$ of the inner and outer zones. This phenomenon must be taken into account when evaluating the transmutation ratio (see Table 4).

\section{CONCLUSIONS}

In this paper, the different distributions of elements containing isotopes for their further transmutation was calculated. The distribution of the neutron flux for both zones of the system, both energy groups and distribution of reaction rates over the core was analyzed. According to this calculation, the optimal location of the isotopes Am and $\mathrm{Np}$ for their transmutation is the one closer to the neutron source (heterogeneous case).

The burnup calculation for two distributions of the elements Pu+MA in the fast zone was carried out for 360 days at nominal power with a step of 30 days. It showed that the variant with the layout of all fuel cells directly near the neutrons source worsens greatly the multiplicative parameters of the system as a whole. Therefore, the second variant, with more homogeneous layout of the elements $\mathrm{Pu}+\mathrm{MA}$ in the fast zone, showed better results in terms of the transmutation rate.

Data obtained as a result of calculating MAs transmutation rates are correlated with similar calculations for other projects of subcritical systems. There is a decrease in the isotopes Am concentration by $7 . .10 \%$, in relation to isotopes $\mathrm{Pu}-$ its production in the system is halved due to the process of transmutation in elements $\mathrm{Pu}+\mathrm{MA}$. The production of ${ }^{238} \mathrm{Pu}$ increases from 2.6 to $45.7 \%$. Transmutation of the isotopes $\mathrm{Cm}$ is not possible under these conditions, their concentration increases by $5 \ldots 14 \%$, considering that the isotopes $\mathrm{Cm}$ do not have a significant contribution to the total radio- toxicity of spent nuclear fuel, other than the isotopes Am and $\mathrm{Np}$, so their transmutation is not critical.

This research was carried out with the financial support of the IAEA, within the terms and conditions of the Research Contract 20638 in the framework of the Coordinated Research Project (CRP) "Accelerator Driven Systems (ADS) Applications and use of Low-Enriched Uranium in ADS (T33002)" within the project "The Two-Zone Subcritical Systems with Fast and Thermal Neutron Spectra for Transmutation of Minor Actinides and Long-Lived Fission Products". The authors are grateful to Alina Dembitskaya for the help in preparing this article.

\section{REFERENCES}

1. T. Wakabayashi. Transmutation characteristics of MA and LLFP in a fast reactor // Progress in Nuclear Energy. 2002, v. 40, p. 457-463.

2. V. Gulik, A.H. Tkaczyk. Cost optimization of ADS design: Comparative study of externally driven heterogeneous and homogeneous two-zone subcritical reactor systems // Nuclear Engineering and Design. 2014, v. 270, p. 133-142.

3. S. Taczanowski. Transmutations of nuclear waste in accelerator-driven subcritical systems // Applied Energy. 2003, v. 75, p. 97-117.

4. R. Li, X.-N. Chen, L. Andriolo, A. Rineiski. 3D numerical study of LBE-cooled fuel assembly in MYRRHA using SIMMER-IV code // Annals of Nuclear Energy. 2017, v. 104, p. 42-52.

5. A. Talamo, Y. Gohar, S. Sadovich, H. Kiyavitskaya, V. Bournos, Y. Fokov, C. Routkovskaya. High enriched to low enriched fuel conversion in YALINA Booster facility // Progress in Nuclear Energy. 2014, v. 70, p. 43-53.

6. Y. Gohar, I. Bolshinsky, D. Naberezhnev, et al. Accelerator-driven subcritical facility: Conceptual design development // Nuclear Instruments and Methods in Physics Research Section A: Accelerators, Spectrometers, Detectors and Associated Equipment. 2006, v. 562, p. 870-874.

7. V.A. Babenko, V.I. Gulik, L.L. Jenkovszky, V.M. Pavlovych, E.A. Pupirina. On the Subcritical Amplifier of Neutron Flux based on Enriched Uranium / Tomas Čechák; László Jenkovszky; Iurii Karpenko (Eds.). Nuclear Science and Safety in Europe. Springer Heidelberg, 2006, p. 253-263.

8. V.O. Babenko, V.I. Gulik, V.M. Pavlovych. The New Research Subcritical Reactor driven by a Highintensity Neutron Generator for Transmutation of the Nuclear Waste // Proceedings of International Conference "Current Problems in Nuclear Physics and Atomic Energy" (NPAE2010), Kyiv, Ukraine: 7-12 June, 2010.

9. V.O. Babenko, V.I. Gulik, V.M. Pavlovych. The Research Subcritical Reactor // Nuclear Physics and Atomic Energy. 2008, v. 9(1), p. 56-61.

10. V.A. Babenko, V.I. Gulik, V.M. Pavlovych. Modelling of two-zone accelerator-driven systems // Nuclear Physics and Atomic Energy. 2012, v. 13(3), p. 266-275.

11. V.I. Gulik. Simulation of fuel distribution in the inner fast zone for two-zone subcritical reactor // 
Nuclear Physics and Atomic Energy. 2017, v. 18(4), p. 331-340.

12. D.O. Sheliahovskyi, V.I. Gulik, A.V. Nosovskyi. Investigation of geometry and fuel composition in two-zone subcritical research reactor for nuclear waste transmutation // Problems of Atomic Science and Technology. 2018, N 114(2), p. 50-56.

13. http://cra.iaea.org/crp/project/ProjectDetail?p rojectId=2167\&lastActionName=OpenedCRPList (accessed 13.02.19).

14. J. Leppänen, M. Pusa, T. Viitanen, V. Valtavirta, T. Kaltiaisenaho. The Serpent Monte
Carlo code: Status, development and applications in 2013 // Annals of Nuclear Energy. 2015, v. 82, p. 142150.

15. T. Kooyman, L. Buiron, G. Rimpault. A comparison of curium, neptunium and americium transmutation feasibility // Annals of Nuclear Energy. 2018, v. 112, p. 748-758.

16. Workshop on Hybrid Nuclear Systems for Energy Production, Utilization of Actinides and Transmutation of Long-lived Radioactive Waste, Trieste, Italy, 3-7 September 2001.

Article received 14.02.2019

\section{МОДЕЛИРОВАНИЕ ТРАНСМУТАЦИИ ПЛУТОНИЯ И МИНОРНЫХ АКТИНИДОВ В ДВУЗОННОМ ПОДКРИТИЧЕСКОМ РЕАКТОРЕ}

\section{В.И. Гулик, Д.О. Шеляговский, А.В. Носовский}

Представлены исследования трансмутации плутония и минорных актинидов в двузонном подкритическом реакторе, управляемом мощным нейтронным генератором. В рамках данной работы были получены распределения потоков тепловых и быстрых нейтронов в представленной двузонной подкритической системе. Также были получены распределения скоростей реакций деления и радиационного захвата для изотопов ${ }^{237} \mathrm{~Np}$ и ${ }^{243} \mathrm{Am}$. Моделирование трансмутации плутония и минорных актинидов было выполнено с помощью МонтеКарло кода Serpent. Представленное моделирование выполнялось для двух разных конфигураций внутренней (быстрой) зоны подкритического реактора. Полученные результаты были проанализированы с точки зрения возможностей эффективной трансмутации плутония и минорных актинидов в двузонных подкритических системах.

\section{МОДЕЛЮВАННЯ ТРАНСМУТАЦІЇ ПЛУТОНІЮ ТА МІНОРНИХ АКТИНІДІВ У ДВОЗОННОМУ ПІДКРИТИЧНОМУ РЕАКТОРІ}

\section{В.І. Гулік, Д.О. Шеляговський, А.В. Носовський}

Представлено дослідження трансмутації плутонію та мінорних актинідів у двозонному підкритичному реакторі, що керується потужним нейтронним генератором. У рамках даної роботи були отримані розподіли потоків теплових та швидких нейтронів у представленій двозонній підкритичній системі. Також були отримані розподіли швидкостей реакцій поділу та радіаційного захоплення для ізотопів ${ }^{237} \mathrm{~Np}$ та ${ }^{243} \mathrm{Am}$. Моделювання трансмутації плутонію та мінорних актинідів було виконано за допомогою Монте-Карло коду Serpent. Представлене моделювання виконувалося для двох різних конфігурацій внутрішньої (швидкої) зони підкритичного реактора. Отримані результати були проаналізовані з точки зору можливостей ефективної трансмутації плутонію та мінорних актинідів у двозонних підкритичних системах. 